\title{
THE PHENOMENON OF ISLAMIC IDENTITY IN THE RELIGIOUS AND CULTURAL CONTEXT OF ISLAMIC PHILOSOPHY
}

\author{
${ }^{1}$ M.K. Bektenova, ${ }^{2}$ N.L. Seitakhmetova, ${ }^{3}$ L.N. Toktarbekova
}

\begin{abstract}
The authors of the article, through the prism of the formation of Islamic identity in traditional Islamic society, try to identify the main cultural, philosophical and religious concepts of the phenomenon of Islamic identity. The 21st century is becoming a century of global changes. The world of Islam and the world around Islam are changing. Wars, revolutions in the Islamic world, mass migrations of Muslims to Western Europe, the promotion of radicalism, terrorism, the development of a zero degree of tolerance in open societies, inter-confessional and intraconfessional intolerance once again served to open up in the humanities the problem of modernizing Islamic consciousness, Islamic philosophical and cultural thought, and also the main issues of the relationship between Islamic tradition and modern conditions. Islamic identity as the main component of the Islamic worldview today must be correlated with the new conditions of political, socio-economic and cultural transformation. Nevertheless, for an adequate understanding and knowledge of Islamic identity, it is important to conceptualize its foundations associated with the religion of Islam itself and the Islamic tradition. Islamic consolidation around the Islamic system of values forms the Muslim ummah, which is one of the main components of Muslim self-identification.
\end{abstract}

Keywords: Islamic Identity, Muslim Philosophy, Ummah, Quran, Islamic Consolidation.
${ }^{1}$ Kazakhstan Institute for Strategic Studies under the President of the Republic of Kazakhstan, Nur-Sultan, Kazakhstan
2,3 Institute for Philosophy, Political Science and Religious Studies of the CS MES RK, Almaty, Kazakhstan
Corresponding Author:
L.Toktarbekova, laura80kz@mail.ru
Reference to this article:
Bektenova M.K., Seitakhmetova N.L.,
Toktarbekova L.N.
The Phenomenon of Islamic Identity in the Religious and Cultural Context of Islamic Philosophy // Adam alemi. - 2021. - No. 2 (88). - P. 122-131.

This research was funded by the SC MES RK (Grant No. AP08855962 «Modern Islamic Philosophy as a New Humanitarian Knowledge: Discourse and Praxis»)

\section{Ислам философиясының діни-мәдени контекстіндегі ислами бірегейлік феномені}

Аннотация. Мақала авторлары дәстүрлі ислам қоғамында исламдық бірегейлікті қалыптастыру призмасы арқылы исламдық бірегейлік құбылысының негізгі мәдени, философиялық және діни түсініктерін анықтауға тырысады. XXI ғасыр жаһандық өзгерістер ғасырына айналуда. Ислам әлемі мен исламның төңірегіндегі әлем өзгеруде. Ислам әлеміндегі соғыстар мен революциялар, мұсылмандардың Батыс Еуропаға жаппай қоныс аударуы, радикализмді, терроризмді насихаттау, ашық қоғамдарда төзімділіктің нөлдік дәрежесін дамыту, конфессияаралық және конфессияаралық төзімсіздік тағы бір рет ашылды гуманитарлық ғылымдар исламдық сананы, исламдық философиялық және мәдени ойды модернизациялау проблемасы, сондай-ақ ислам дәстүрі мен қазіргі заманғы жағдайлар арасындағы байланыстың негізгі мәселелері. Исламдық бірегейлік қазіргі кездегі исламдық дүниетанымның негізгі компоненті ретінде саяси, әлеуметтік-экономикалық және мәдени трансформацияның жаңа шарттарымен байланысты болуы керек. Осыған қарамастан, исламдық бірегейлікті тұтас түсіну және білу үшін оның ислам дінімен және ислам дәстүрімен 
байланысты негіздерін тұжырымдау маңызды. Исламдық құндылықтар жүйесінің айналасында исламдық консолидация мұсылмандық өзін-өзі бірегейлендірудің негізгі компоненттерінің бірі болып есептелетін мұсылман үмбетін құрайды.

Түйін сөздер: ислами бірегейлік, мұсылман философиясы, үммет, Құран, ислами бірігу.

\title{
Феномен исламской идентичности в религиозно-культурологическом контексте исламской философии
}

\begin{abstract}
Аннотация. Авторы статьи сквозь призму формирования исламской идентичности в традиционном исламском обществе пытаются выявить основные культурфилософские и религиозные концепты феномена исламской идентичности. XXI столетие становится веком глобальных изменений. Меняется мир ислама и мир вокруг ислама. Войны, революции в исламском мире, массовые миграции мусульман в страны Западной Европы, продвижение радикализма, терроризма, развитие нулевой степени терпимости в открытых обществах, межконфессиональная и внутриконфессиональная нетерпимость вновь послужили открытию в гуманитарной науке проблемы модернизации исламского сознания, исламской философско-культурологической мысли, а также основных вопросов взаимоотношения исламской традиции и современных условий. Исламская идентичность как основной компонент исламского мировоззрения сегодня должна быть соотнесена с новым условиям политической, социально-экономической и культурной трансформации. Тем не менее, для адекватного понимания и познания исламской идентичности важна концептуализация ее основ, связанных с самой религией ислам и исламской традицией. Исламская консолидация вокруг исламской системы ценностей образует мусульманскую умму, которая является одним из основных компонентов самоидентификации мусульман.
\end{abstract}

Ключевые слова: исламская идентичность, мусульманская философия, умма, Коран, исламская консолидация.

\section{Introduction}

The development trends of the modern historical and philosophical process are determined by socio-economic, political, technogenic and civilizational factors. They actually "provoke" some new techniques for understanding this process itself. In modern Muslim philosophy, striving to acquire its independent status, there are also many problems that need to be reconstructed and re-actualized. Among such problems at the junction of the social sciences and humanities, the phenomenon of Islamic identity should be highlighted. Muslim or Islamic identity is one of the main mechanisms of socialization through a person acquiring the value orientations of Islam. Muslim identity is diverse and dynamic; it should be viewed both as a state and as a process. In other words, Muslim identity, like any other, is not a static phenomenon, and it is subject to change, since it is in the sphere of interfaith relations that religious norms and behavioral models are modified [1, p. 233].

Nevertheless, it is not always easy to understand the use of the analyzed term; as a rule, one must proceed from the general context of the work in which this concept is used. The ambiguity of the category of Muslim identity is explained by the complexity of its genesis. It seems that the problem of conceptualizing Muslim identity is of particular importance. This is especially noticeable in the conditions of secular states of the post-secular world.

\section{Methodology}

The problem of Islamic identity is complex, ambiguous, multidimensional, to reveal its phenomenological content, conceptualization, significance in the context of modern socio-political processes, methodological foundations of such humanitarian sciences as philosophy, religious studies, cultural studies, political science, and Islamic studies are needed.

In this connection, the use of various methods and methodological attitudes in the article was justified, including: methods of historical and logical reconstruction, phenomenology of religion, religious and philosophical comparative studies, Koranic methods (tafsir). 


\section{Main part}

With the development of national selfawareness, the search for identity, the identity crisis, a radical turn towards their spiritual roots and spiritual source for Muslims, the need to comprehend and reconstruct the main ideological constructs of Muslim philosophy has become actual.

From the very beginning, identity in Islam was directly related to the Islamic ummah and the observance of Islamic principles of life, the main of which was the principle of Islamic ethics. Ethical laws, which were conceptualized on the fundamental principles laid down in the Quran and Sunnah, formed Islamic jurisprudence - figh - and extended it to the entire structure of human life.

Since the Islamic legal aspect was a moral aspect, therefore, a person who considered himself a Muslim followed them. The legal consciousness of a Muslim is a moral consciousness that is based on the observance of norms that are also considered moral.

Linking law and morality in Islamic identity is a distinctive feature among identities: cultural, national, political, etc.

So, Islamic identity is formed on the moral and legal laws of Islam, moreover, individuality and collectivity in Islamic society are an organic whole, since a single moral law prevails over them.

The identification of a Muslim is identified with such moral principles in Islam as piety, mercy, patience, repentance, adherence to the basic fundamental principles: shahada, salat, saum, zakat, hajj, and most importantly, faith in one God. Halal and haram phenomena also draw ontological boundaries of Islamic identity.

Islamic communication or Islamic solidarity is defining in Islamic identity. If in the Christian religion there is a provision that communication with other people, relatives leads away from the fulfillment of the commandments [2], then in the Islamic tradition family ties and their maintenance is a godly deed. Perhaps that is why Islamic solidarity in dialogical communication forms an idea of family values, and a
Muslim from social institutions perceives the institution of the family as an institution that has the most favorable influence on the formation of Islamic identity.

Islamic identity is revealed, in general, in Islamic life attitudes and their observance: Islamic rituals, Islamic holidays, Islamic education, Islamic enlightenment. Islamic identity in the Middle Ages was universal at its core, but we should not forget that it appears at the beginning as based on Arab identity, but since Islam is a universal faith, transnational, it lacks the question of God's chosenness, since Islam opens up to all who wants to follow the laws of the Quran.

In the historical and cultural space of the Arab Caliphate, multiculturalism prevailed: the various peoples inhabiting it lived by their own religious traditions, observing the norms and rules of life. There was adat - a codified legal constitution uniting members of a society. Identifying himself according to social laws, spiritual and cultural tradition, a person who has not yet become a Muslim honors his own laws, the laws of the tribe, family, etc.

With the advent of Islam, the picture changes: from an anthropocentric person he turns into a completely different person who correlates himself with Islam. If during the formation of Islam identity was determined only by belonging to the Islamic ummah, then later, it is determined by many factors and provisions of a doctrinal nature.

Islamic theologians-mutukallim were the first to talk about Islamic identity as a problem, and they elevated it into a metaphysical discourse. In relation to Islamic laws and their observance, Islamic identity is conceptualized and constructed. The fact that there were many schools of thought dealing with Islamic issues in the Kalam played a role in the relatively universal interpretation of Islamic identity.

Probably, it is necessary to understand the historical reality of those centuries in order to separate concepts such as Islamic identity and ethnic identity, this also applies to traditional society.

What is traditional Islamic society? First of all, a traditional Islamic society is a society that has not only been formed under the 
influence of Islamic tradition, but also one that forms Islamic traditional identity.

The problem of Islamic identity is connected in general with the problem of the formation of Islamic consciousness and the processes in which the Islamic world is involved today.

The most difficult thing is to conceptualize the phenomenon of Islamic identity today, in a society that we call post-secular, since Islam plays a very significant role in it and despite the fact that post-secularity will be the main trend in the near future, its influence, i.e., Islam, will increase...

Islamic identity is the identification of a person, a society with an Islamic cultural, religious tradition and an Islamic society - the ummah, in general with the Islamic world. It should be noted that Islamic identity is collective, since its ontological characteristic is the awareness of identity through the ummah. However, the transformations that are taking place in society today show that there are also personal development of the identification process by the Islamic tradition, especially this can be traced in the phenomena of religious conversion: the transition from one confession to another (traditional, non-traditional, etc.).

A traditional society is a society in which adherence to tradition is considered unshakable: spiritual, cultural, religious. There are a lot of definitions of traditional society in the scientific literature. For many years, the definition of traditional society took place only from the standpoint of modernism, in which traditional societies were understood as rigid, conservative societies that did not strive for progress and innovations. However, today the understanding of traditional society has radically changed. Scientists such as $Z$. Bauman, R. Putnam and others believe that it is the adherence to tradition that has a positive impact on the formation of modernization projects, and the institutions of tradition are ready for an organic balance with innovative projects.

Throughout the history of the development of societies, transformational processes took place that required changes in the way of life, breaking traditions, etc. However, tradition and modernization are in constant unity, while rejection of tradition is fraught with a change in value paradigms. Today the traditional society is developing in different political and socio-cultural conditions. The historical experience of traditional societies shows that modernization results can be achieved precisely as a result of preserving one's own tradition: religious, cultural, etc. As examples, one can point to the traditional experience of Japan, China, and a number of countries of the Islamic world.

The Islamic world and the problem of transformation of traditional society is a complex topic, we are interested in it in this study because it was in the traditional society that the formation of religious or traditional identity initially took place. Outside of tradition, it is generally impossible to pose this problem, which is why it is necessary to make an excursion into historical reality, where the process of identification of a person and society with the Islamic tradition took place.

Ummah or society, nation means an Islamic community that has evolved historically and was sealed by the tradition of the Islamic faith. It is believed that the formation of the ummah is completed in 622. The texts of the Koran speak of the social and cultural significance of the Ummah as a unifying force, moreover, the expediency of uniting into a community is associated with the fulfillment of the main pillars of Islam. In the beginning, the Ummah was understood only as the Medina union of the first Muslims and Jews, where the laws of joint social residence were formed, later only Muslims are considered the Ummah, it becomes the Islamic Ummah

Gradually, the Islamic mind is identified with the concept of "dar al-Islam" and becomes a marker of the Islamic sociocultural space. I would like to draw attention to the linguistic subtlety of the terms "ummah" and "al-ummah", where the first was used to refer to the community in general, and the second to the community 
of Muslims, although the non-Muslim community is also called "dar al-harb". The Ummah is still used today in different senses: a nation, a religious community: umma arabiyya, ummah islamiyya, etc., in the global cultural space the ummah today bears the meaning of the Islamic community.

The Ummah and its identification as a Muslim society is determined through the Islamic tradition, and an Islamic traditional society is a society in which Islamic values, laws prevail, and an Islamic way of life is cultivated. In such a society, the process of the formation of Islamic identity is taking place.

In the suras of the Koran: "Al-Anam", "Al-Anfal" 8:72, "An-Nahl" 16: 120, "Hood" 11: 48-50, "Al-Imran" 3:68, "Muhammad" 47:11, "An-Nisa" 4:75 and others, there are conceptual definitions of the ummah and its meaning for the formation of an Islamic way of life, in principle, an Islamic identity.

Ayat 38 of Surah Al-Anam (Cattle) reveals the meaning of the Ummah for man: "There is no animal on earth and a bird flying on wings that would not be communities like you. We did not miss anything in the Book, then they will be gathered to your Lord". Thus, living in society, according to the Koran, is an ontological necessity, since only in society can a person realize himself as a person, realize his own abilities. Surah "An-Nahl" substantiates the doctrine of justice, which should be basic in the ummah, through which the people of the ummah unite, trust each other, respect each other, recognizing different points of view and opinions. The principles of ijtihad and shura clearly operate in the ummah.

ljtihad, as the ability to reflect on the Qur'anic precepts, is a way of rationalistic comprehension by a Muslim of the most complex issues, including those related to issues of Islamic identity. Shura, as the realization of ijma, expresses the unity of the ummah. The concept of "ummah" meant at the beginning of the spread of Islam, like the word "millat" - religion, and only in the Meccan period of the Prophet Muhammad's activity does it acquire a social, cultural, religious meaning, that is, polysemantic, becoming an expression of spiritual strength and bearer Islamic tradition, Islamic way of life.

And if at the beginning the ummah had a local meaning, i.e. meant belonging to the community of Medina, then later, locality, belonging to a tribe is deconstructed in it, the unity of those who believed in Allah and the prophetic mission of Muhammad is constructed in it.

Today the Ummah is defined as a transnational Muslim community. Islamic identity is formed in the ummah, since it is a social organization that translates the principles and norms of the Islamic tradition. Islamic identification occurs in accordance with the implementation and observance of the basic provisions of Islam, which form the foundation of the Islamic tradition:

- Belief in Allah and recognition of the mission of the Prophet Muhammad (shahadah).

- Salat (namaz) - five times prayer.

- Saum (fasting).

- Zakat (tax in favor of the poor).

- Hadj (pilgrimage to Mecca) [3, p. 413].

Actually, the observance of these five pillars of Islam is the quintessence for the formation of Islamic identity. However, it is necessary to note the role of cultural and ethnic traditions in this issue, which introduce the problem of Islamic identity into the discourse of national traditionalism.

First of all, we are talking about the division of Islam into Sunnism, Shiism, which appears in 632 in connection with the death of the Prophet Muhammad. The division itself had a purely political significance and concerned more of the discourse of power, the issue of the legal inheritance of power in the Ummah, rather than sociality. Nevertheless, this was the very first split of the ummah, but which did not have a cardinal impact on the change of Islamic identity.

It should be noted that precisely from this period - the first split of the Ummah, a theological discussion begins on 
various problems of man and society. The formation of madhhabs in the 10th century contributed to the formation of an Islamic identity corresponding to the madhhabs. If in Sunnism the "closing of the gates of ijtihad" contributed to the formation of traditional Islamic identity, then in Shiism, where there was no "closure of ijtihad", identity was defined in the context of "ahl al-beit". The Kharijites, who had already opposed the followers of Ali, initiated the second split in the Ummah. Later, the Kharijites advocated the election of power and the formation of an Islamic identity, which should be carried out in opposition to those who profess tolerance towards dissidents.

The well-known concept "At-takfir wa-I-hijra" - "accusation of disbelief and withdrawal from the world", which was the ideology of representatives of the radical movement "Muslim Brotherhood" in the person of Seyid Muhammad Qutb [3, p. 1143] appears to be a partial restoration of Kharijism.

Islamic culture, cultural Islamic formation, is a condition for the development of Islamic identity. Its formation in the cultural tradition is associated with the social and spiritual transformations that are taking place and were carried out in the process of the Islamization of the regions and the ethnic groups living in them. So, Islamic identity is the identification of a person and society with the Islamic tradition. However, ethnic groups were already carriers of their own cultural tradition and language, therefore, they were already identified. Islamization took place gradually, "evolving" under those traditions that did not fundamentally contradict the Islamic system of values. This, for example, happened with the Turkic traditions. The Türkic identity does not undergo a radical change, but the Islamic tradition changes the religious consciousness. Turkic identity and Islamic identity are distinguished by religious tradition, but they are united in moral priorities: freedom, humanism, solidarity, mutual respect. As an example, we can cite the history of the formation of Islamic identity during the rule of the Karakhanid dynasty in the Turkic regions of the Arab Caliphate.

The rule of the Karakhanids influenced the formation of Islamic identity as stable, since the identity paradigm itself was formed during this period. It is known that the era of the Karakhanids, on the one hand, contributed to the development of the Turkic identity, on the other hand, it implemented the traditional values of Islam.

Defining the Türkic identity as identification only with the Türkic tradition, we do not achieve the completeness of its understanding and representation. Türkic identity is defined through Türkic culture. With regard to the Turkic identification process, a number of examples can be cited when acculturation took place in the Turkic tradition and vice versa. However, the history of Turkic culture has shown that the stable components of Turkic culture - language, customs, art, religion - have preserved their Turkic identity, which has not changed dramatically even in the process of Islamization.

The Islamization of the Turkic consciousness was carried out gradually, without causing radical resistance. The struggle for the preservation of the Turkic language and Turkic traditions begins, for example, on the territory of Kazakhstan, later. Let us consider the phenomenon of Turkic identity, its genesis, transformation in the context of Kazakh culture, since in this region there were processes that, on the one hand, were common, but on the other hand, they were unique, since they became possible only in the cultural space of Kazakhstan. For this study, the topic of Turkic identity is relevant, since outside of its consideration it is impossible to comprehend and identify the essence of the phenomenon of Kazakh Islamic identity, since it was formed under the direct influence of the Turkic tradition. The experience of the development of the Turkic tradition shows that tolerance and ethical imperatives have become basic in the Turkic identity, they then fit into the Islamic content and form the Kazakh Islamic identity. 
The traditional Turkic society on the territory of Kazakhstan was nomadic, therefore, the value worldview principles corresponded to it. One of the important components that contributed to the formation of the Turkic identity was communication, the communicative capabilities of the Turkic culture. It became an indicator of the freedom and openness of the nomads. Communication with other religious traditions contributed, on the one hand, to the openness of the nomads, but on the other hand, to closeness, it is in this relationship that the Turkic identity develops. Islamic identity in the realities of the Turkic world contains the traditions of the culture of the Turks, on the example of Kazakhstan, we can see this in such a phenomenon as "Kazakh Islam".

The development of identity is influenced by social factors, psychological, personal. The alternativeness of identities and their acceptance lies not only in historical conditions, but also in something else, the presence in them of a similar spiritual content.

Islam is not originally ethnic, unlike, for example, Hinduism, Judaism, it was positioned as a universal teaching, a universal message "from God, therefore, the distinction by ethnicity was not the most significant for the Islamic faith, much more significant was the understanding of the exclusive "universalism" and on the basis of this identification in the context of the universalism of Islam. The traditional society of the Turks with the adoption of Islam is universalized in the spiritual tradition. The Caliphate, which fulfilled not only the role of a geopolitical and religious association, was transnational until 1258 , i.e. before the Mongol expansion. Since 1258, the process of "ethnic traditionalization" of Islamic identity begins again, but in different historical conditions. Actually, Islamic identity in different regions of the Caliphate always contained ethnicity, ethno-traditionalism, but, nevertheless, the desire to universalize Islamic identity prevailed, and from the 13th century this process will be more pronounced. Today, Islamic identity is presented in the Islamic world as an ethnoidentity, since the process of Islamization is still carried out as a process of national identity in the countries of the Arab East, Africa, Asia, Iran, Turkey, India, etc. However, it should be noted that despite ethno-traditionalism, nevertheless, Islamic identity is universalized in the context of Sunnism, which makes up about $90 \%$ of believers and Shiism, the remaining 10$15 \%$ of Muslims are ranked among them.

So, in the traditional Islamic society the ummah - identity was defined by:

- adherence to the five pillars of Islam (shahadah, salat, saum, zakat, hajj);

- recognition of the main fundamental primary sources: the Koran and the Sunnah;

- modeling of Islamic life in relation to Islamic law: figh, which constitutes the doctrine of laws - sharia;

- recognition of madhhabs and reckoning to one of them (Hanafi madhhab, Maliki, Shafi'i, Hanbali) [4, p. 162-163].

The issue of the formation of Islamic identity in a traditional society would not be entirely clear without considering the history of various trends in Islam, which have influenced and continue to influence the development and formation of Islamic identity in traditional societies.

The trends or trends in Islam developed mainly as intellectual and scientific (falsafa, adab, mutazilism) and intellectual and theological (kalam, figh), in addition, intellectual and mystical (Sufism). All these areas united around the problems that were raised by representatives of madhhabs, theology, fiqh, philosophy, philology. In addition, there were different trends within Islam. Pluralism in the interpretation of the rights and freedoms of a Muslim was not the privilege of any madhhab, but a common attitude, since thinking about everything that was conveyed by the Prophet Muhammad had to be meaningful.

Rationalistic methods of understanding were recognized even by well-known representatives of the Kalam, the founders of the madhhab, for example, such a representative is Abu Hanifa, the founder of the Hanafi madhhab, to which the Muslims 
of modern Kazakhstan refer to themselves, positioning themselves in Islamic identity as the Sunnis of the Hanafi madhhab.

By the way, the well-known statement of the Prophet Muhammad that pluralism in opinions is the grace of Allah played a positive role in the formation of Islamic tolerance and recognition of the legitimacy of all the madhhabs that have developed as Islamic schools of law. Of course, the differences between the madhhabs of Islamic law from each other played a significant role in the formation of Islamic identity in a particular socio-cultural area. T. Ibrahim notes that the Hanbali school-madhhab has played and is playing a significant role in the formation of Islamic identity based on a very "rigid, literal" interpretation of the Qur'anic text, intolerance to various innovations, dissidents, exceptionally strict implementation of Islamic rituals, observance of Sharia norms; the adherents of the Hanbali madhhab include the Wahhabis [4, p. 163].

Nevertheless, in its true understanding, the Qur'anic picture of cognition is, first of all, the cognition of human nature through the diversity and unity of things. The ontological question of the Qur'an is essentially a question of the unity of the world. It is from the principle of monism that the tawhid teaching, Islam, is derived. Islam is sent to man as his salvation on Earth. Thanks to this teaching, a person becomes that essence of himself, which means the concept of "person" [5, p. 16].

The personality of a Muslim in modern society is strikingly different from the personality of a Muslim in the Middle Ages, and even in the twentieth century, since the dynamically developing world forms mobile communication connections. Integration into scientific, educational, political, socioeconomic processes contributes not so much to "collectivization" as to individualization. A Muslim today lives in the space of different cultures and worlds, dominated by other religious traditions, neoliberal-democratic values, he is embedded in the era of life ideals of post-secularism.

However, the dynamics of Islamic identity shows that there is a stability of
Islamic identification, which if it changes, then only in the direction of the past, to the return of the classical ideologemes of Islamic identity, and even Muslim modernism in the person of Muhammad 'Abduh [6], Afghani [7], Tibi [8], Sardar [9], and Ramadan [10], with all their aspirations to enter an open society, modernized Islamic consciousness as a set of classical Islamic identities and modern ones, ready for dialogue with the new time and its ideological constructs.

The well-known course of the renewal of Islam - Euro-Islam has become a new concept for the development of the integration of Muslims in European societies. There is a need to conceptualize the problems of Islamic consolidation, trust, solidarity, cooperation, security, and the formation of an information and communication space.

Appearing as a concept in the XX century "Euroislam" has become a phenomenon of modern life and postmodern dialogic strategy. Today Euroislamic passion is determined, on the one hand, as clean demarcation line Islamic and European values, on the other hand, as non-linearity of dialogical paradigm, which is important to identify as Euroislamic. Discursively of Euroislam is in line with the philosophical reflection on Islamic and European theme. What, exactly, can offer Euroislam? The most important and urgently needed is a dialogue. By installing the dialogic general line Euroislam is not just tolerant plant, but a positive way of life existential understanding of communication practices of modernity [11, s. 99].

It is necessary to note the contribution of the famous scientist Olivier Roy to the development of this problem, who raised the issue of promoting post-Islamist ideologies, neofundamentalist, the theory of globalized Islam, inhibiting the processes of Islamic revival [12].

\section{Conclusion}

The phenomenon of Islamic identity today has no categorical clarity, and an integrated approach is required 
to understand this phenomenon. The problematic issues of this area of knowledge are not yet clearly defined, the conceptual apparatus is in the stage of formation, and the main directions of research will range from dividing concepts to integration and dialogical concepts of scientists and politicians.

An analysis of the problematic field of research related to Islamic topics shows that in recent years the question of Muslim self-identification has become especially acute. The very understanding of Muslim identity is being transformed along with the socio-cultural conditions of the existence of Muslims.

The appeal of socio-humanitarian science to the concept of Muslim identity is associated with the growing role of the Islamic factor in the political life of modern states. In this connection, interest in the global problems of Islam will remain relevant for a long time. And only religious studies, philosophical, as well as conceptual and methodological identification of its meaning and meaning is relevant to modern humanitarian discourse and praxis, allowing deeply reveal Islamic identity as a spiritual and cultural identification of a person and society with the Islamic world (Islamic tradition, culture, consciousness). And the possibilities of preserving Islamic identity are in the organic connection of the Islamic tradition, Islamic upbringing, education and integration into the postsecular society (socialization, demand for the Islamic tradition, Islamic worldview).

\section{References}

1. Кудряшова И.В. Мусульманская политическая идентичность: единство и многообразие // Идентичность: личность, общество, политика: энцикл. изд. / отв. ред. И.С. Семененко. - М.: Весь мир, 2017. - С. 229-241.

2. Библия. Евангелия от Матфея: 10:34-36.

3. Религиоведение. Энциклопедический словарь / под ред. Забияко А.П., Красникова А.Н., Элбакян Е.С. - М.: Академический проект, 2006. $-1256 \mathrm{c}$.

4. Новая философская энциклопедия в четырех томах. - М.: Мысль, 2010. - Т 2. - 634 с.

5. Сейтахметова Н.Л. Мусульманская средневековая философия / Н.Л. Сейтахметова. - Алматы, 2009. - С. 169.

6. Сейранян Б.Г. Мухаммад Абдо: творец мыслящего Египта // Восток (Oriens). Афро-азиатские общества: история и современность. - 2011. - № 2. - С. 33-44.

7. Афгани С.Дж. Татиммат ал-баян фи тахрих ил-Афган / пред., прим., коммент. и подг-ка к печ. Азимовой Б.Т. - Душанбе, 1999. - 156 c.

8. Tibi B. Islam between Culture and Politics. - Palgrave Macmillan UK, 2005. - 334 p.

9. Sardar Z. Islam, postmodernism and other futures: a Ziauddin Sardar reader / ed. by S. Inayatullah and G. Boxwell. - 2003. - 394 p.

10. Ramadan T. Western Muslims and the Future of Islam. - Oxford, 2004. -274 p.

11. Евроислам как диалогическая стратегия современности (к философскому вопросу о диалоге культур) = Euroislam as a Dialogic Strategy of Modernity (to the Philosophical Question about the Dialogue of Culture): $\phi и-$ лософская монография / Под общей редакцией 3.К. Шаукеновой. - Алматы: Институт философии, политологии и религиоведения KH MOH PK, 2013. - 162 c.

12. Roy O. Globalized Islam: The Search for a New Ummah. - New York: Columbia University Press, 2004. -320 p.

\section{Transliteration}

1. Kudrjashova I.V. Musul'manskaja politicheskaja identichnost': edinstvo i mnogoobrazie [Muslim Political Identity: Unity and Diversity]// Identichnost': lichnost', obshhestvo, politika: jencikl. izd. / otv. red. I.S. Semenenko. M.: Ves' mir, 2017. - S. 229-241. (in Russ)

2. Biblija [Bible]. Evangelija ot Matfeja: 10:34-36. (in Russ)

3. Religiovedenie. Jenciklopedicheskij slovar' [Religious studies. Encyclopedic Dictionary]/ pod red. Zabijako A.P., Krasnikova A.N., Jelbakjan E.S. - M.: Akademicheskij proekt, 2006. - 1256 s. (in Russ)

4. Novaja filosofskaja jenciklopedija $v$ chetyreh tomah [New philosophical encyclopedia in four volumes]. - M.: Mysl', 2010. - T 2. -634 s. (in Russ)

5. Sejtahmetova N.L. Musul'manskaja srednevekovaja filosofija [Muslim medieval philosophy]/ N.L. Sejtahmetova. - Almaty, 2009. - S. 169. (in Russ)

6. Sejranjan B.G. Muhammad Abdo: tvorec mysljashhego Egipta [Muhammad Abdo: Creator of Thinking Egypt]// Vostok (Oriens). Afroaziatskie obshhestva: istorija i sovremennost'. - 
2011. - № 2. - S. 33-44. (in Russ)

7. Afgani S.Dzh. Tatimmat al-bajan fi ta'rih il-Afgan / pred., prim., komment. i podg-ka k pech. Azimovoj B.T. - Dushanbe, 1999. - $156 \mathrm{~s}$. (in Russ)

8. Tibi B. Islam between Culture and Politics. - Palgrave Macmillan UK, 2005. - 334 p. (in Eng)

9. Sardar Z. Islam, postmodernism and other futures: a Ziauddin Sardar reader / ed. by S. Inayatullah and G. Boxwell. - 2003. - 394 p. (in Eng)

10. Ramadan T. Western Muslims and the Future of Islam. - Oxford, 2004. -274 p. (in Eng)
11. Evroislam kak dialogicheskaja strategija sovremennosti ( $k$ filosofskomu voprosu o dialoge kul'tur) = Euroislam as a Dialogic Strategy of Modernity (to the Philosophical Question about the Dialogue of (Culture): filosofskaja monografija / Pod obshhej redakciej Z.K. Shaukenovoj. - Almaty: Institut filosofii, politologii i religiovedenija KN MON RK, 2013. - 162 s. (in Russ)

12. Roy O. Globalized Islam: The Search for a New Ummah. - New York: Columbia University Press, 2004. - 320 p. (in Eng)

\section{INFORMATION ABOUT AUTHORS}

Madina Bektenova

Natalya Seitakhmetova

Laura Toktarbekova

Мадина Кенесарыевна Бектенова

Наталья Львовна Сейтахметова

Лаура Ниязбековна Токтарбекова

Мадина Кенесарықызы Бектенова

Наталья Львовна Сейтахметова

Лаура Ниязбекқызы Тоқтарбекова
$\mathrm{PhD}$, Leading Researcher, Kazakhstan Institute for Strategic Studies under the President of the Republic of Kazakhstan, Nur-Sultan, Kazakhstan

Corresponding-Member NAS RK, Professor, Doctor of Philosophical Sciences, Chief Researcher, Institute for Philosophy, Political Science and Religious Studies of the CS MES RK, Almaty, Kazakhstan

$\mathrm{PhD}$, Leading Researcher, Institute for Philosophy, Political Science and Religious Studies of the CS MES RK, Almaty, Kazakhstan

$\mathrm{PhD}$, ведущий научный сотрудник, Казахстанский институт стратегических исследований при Президенте РК, Нур-Султан, Казахстан

член-корреспондент НАН РК, профессор, доктор философских наук, главный научный сотрудник, Институт философии, политологии и религиоведения КН МОН РК, Алматы, Казахстан

$\mathrm{PhD}$, ведущий научный сотрудник, Институт философии, политологии и религиоведения КН МОН РК, Алматы, Казахстан

$\mathrm{PhD}$, жетекші ғылыми қызметкер, Қазақстан Республикасы президентінің жанындағы Қазақстан стратегиялық зерттеулер институты, Нұр-Сұлтан, Қазақстан

ҚР ҰҒА корреспондент-мүшесі, профессор, философия ғылымдарының докторы, бас ғылыми қызметкер, ҚР БҒМ ҒК Философия, саясаттану және дінтану институты, Алматы, Қазақстан

$\mathrm{PhD}$, жетекші ғылыми қызметкер, ҚР БҒМ ҒK Философия, саясаттану және дінтану институты, Алматы, Қазақстан 